\title{
Contrasting biogeochemistry of nitrogen in the Atlantic and Pacific Oxygen Minimum Zones
}

\author{
E. Ryabenko ${ }^{1}$, A. Kock ${ }^{1}$, H. W. Bange ${ }^{1}$, M. A. Altabet $^{2}$, and D. W. R. Wallace ${ }^{3}$ \\ ${ }^{1}$ Leibniz-Institut für Meereswissenschaften an der Universität Kiel (IFM-GEOMAR), Forschungsbereich Marine \\ Biogeochemie, Düsternbrooker Weg 20, Kiel, Germany \\ ${ }^{2}$ School for Marine Science and Technology (SMAST), University of Massachusetts Dartmouth, 285 Old Westport Road, \\ North Dartmouth, MA, USA \\ ${ }^{3}$ Halifax Marine Research Institute, Dalhousie University, 1355 Oxford Street, P.O. Box 15000, Halifax, Nova Scotia \\ B3H 4R2, Canada
}

Correspondence to: E. Ryabenko (eryabenko@ifm-geomar.de)

Received: 2 August 2011 - Published in Biogeosciences Discuss.: 9 August 2011

Revised: 30 November 2011 - Accepted: 19 December 2011 - Published: 11 January 2012

\begin{abstract}
We present new data for the stable isotope ratio of inorganic nitrogen species from the contrasting oxygen minimum zones (OMZs) of the Eastern Tropical North Atlantic, south of Cape Verde, and the Eastern Tropical South Pacific off Peru. Differences in minimum oxygen concentration and corresponding N-cycle processes for the two OMZs are reflected in strongly contrasting $\delta^{15} \mathrm{~N}$ distributions. Pacific surface waters are marked by strongly positive values for $\delta^{15} \mathrm{~N}$ $\mathrm{NO}_{3}^{-}$) reflecting fractionation associated with subsurface $\mathrm{N}$ loss and partial $\mathrm{NO}_{3}^{-}$utilization. This contrasts with negative values in $\mathrm{NO}_{3}^{-}$depleted surface waters of the Atlantic which are lower than can be explained by $\mathrm{N}$ supply via $\mathrm{N}_{2}$ fixation. We suggest the negative values reflect inputs of nitrate, possibly transient, associated with deposition of Saharan dust. Strong signals of $\mathrm{N}$-loss processes in the subsurface Pacific OMZ are evident in the isotope and $\mathrm{N}_{2} \mathrm{O}$ data, both of which are compatible with a contribution of canonical denitrification to overall $\mathrm{N}$-loss. However the apparent $\mathrm{N}$ isotope fractionation factor observed is relatively low $\left(\varepsilon_{\mathrm{d}}=11.4 \%\right.$ ) suggesting an effect of influence from denitrification in sediments. Identical positive correlation of $\mathrm{N}_{2} \mathrm{O}$ vs. AOU for waters with oxygen concentrations $\left(\left[\mathrm{O}_{2}\right]<5 \mu \mathrm{mol}^{-1}\right)$ in both regions reflect a nitrification source. Sharp decrease in $\mathrm{N}_{2} \mathrm{O}$ concentrations is observed in the Pacific OMZ due to denitrification under oxygen concentrations $\mathrm{O}_{2}<5 \mu \mathrm{mol}^{-1}$.
\end{abstract}

\section{Introduction}

Nitrogen is a key limiting element for biological productivity and occupies a central role in ocean biogeochemistry
(Gruber, 2008). Although most chemical forms of nitrogen in the ocean are bio-available (i.e. fixed nitrogen or "fixed$\mathrm{N}$ ") the most abundant form, $\mathrm{N}_{2}$ is generally not. The sources of fixed-N include river inputs, atmospheric deposition and $\mathrm{N}_{2}$ fixation (Duce et al., 2008; Gruber, 2008). Sinks of fixed-N, producing $\mathrm{N}_{2}$, include microbial denitrification and anammox processes, both requiring very low (i.e. suboxic) $\left[\mathrm{O}_{2}\right]$ (Devol, 2008). Hence suboxic Oxygen Minimum Zones (OMZs) are the oceanic regions especially associated with denitrification (Cline and Richards, 1972; Codispoti et al., 2001; Ward et al., 2009) and anammox (Lam et al., 2009; Thamdrup et al., 2006; Hamersley et al., 2007; Galan et al., 2009) and play a particularly important role in the global nitrogen cycle as sites of $\mathrm{N}$ sinks from the ocean. They are located typically in areas of upwelling with high productivity which exhibit complex cycling of nutrients (Helly and Levin, 2004).

The relative importance of heterotrophic denitrification (a stepwise reduction process involving a number of intermediates, $\mathrm{NO}_{3}^{-} \rightarrow \mathrm{NO}_{2}^{-} \rightarrow \mathrm{NO} \rightarrow \mathrm{N}_{2} \mathrm{O} \rightarrow \mathrm{N}_{2}$ ), compared to autotrophic anammox (a chemosynthetic process, $\mathrm{NO}_{2}^{-}+$ $\mathrm{NH}_{4}^{+} \rightarrow \mathrm{N}_{2}$ ) has been debated (Voss and Montoya, 2009; Koeve and Kähler, 2010).

Absence of ammonium in suboxic OMZs that should have accumulated from organic matter breakdown could be indicative of anammox, while the consumption of $\mathrm{N}_{2} \mathrm{O}$ requires the denitrification process (Naqvi et al., 2010).

Although OMZs are found in all major ocean basins, their associated nitrogen cycle processes can vary dramatically due to contrasting minimum oxygen levels. In the Eastern Tropical South Pacific (ETSP), suboxic 
$\left(\left[\mathrm{O}_{2}\right]<5 \mu \mathrm{mol} \mathrm{l}^{-1}\right)$ conditions are found, whereas in Eastern Tropical North Atlantic (ETNA), more relaxed conditions exist $\left(\left[\mathrm{O}_{2}\right]>40 \mu \mathrm{moll}^{-1}\right)$ (Karstensen et al., 2008). In addition, fixed-N inputs associated with atmospheric deposition and, possibly, $\mathrm{N}_{2}$-fixation, vary between the two regions (Chavez and Messie, 2009).

Cruises carried out during the collaborative research project SFB-754 (www.sfb754.de) of the German Research Foundation and the BMBF supported project SOPRAN (Surface Ocean Processes in the Anthropocene: www.sopran. pangaea.de) provided unique opportunities to sample nitrogen species in these two contrasting regions. Here we present a comparison of $\mathrm{N}_{2} \mathrm{O}$ concentration and stable nitrogen isotope distributions, which were measured in both OMZs to highlight the similarities and differences in nitrogen cycling between the two regions.

\section{Sampling and analytical methods}

In the Pacific OMZ, samples were collected onboard the R/V Meteor (M77 Legs 3 and 4) in December 2008 and January 2009 (Fig. 1). In the Atlantic OMZ, samples were collected on the R/V L'Atalante (cruise leg ATA03) during February 2008 from Dakar to Cape Verde Islands and on the R/V Meteor (M80) in December 2009 covering the region south to Cape Verde Islands. At each station, water samples were collected using 121 Niskin bottles on a CTD rosette system equipped with temperature, pressure, conductivity and oxygen sensors. Nutrients and oxygen were determined onboard according to Grasshoff et al. (1999). Triplicate water samples were taken from the CTD/rosette casts and were analyzed for dissolved $\mathrm{N}_{2} \mathrm{O}$ onboard using a static equilibration method. For details concerning the $\mathrm{N}_{2} \mathrm{O}$ method, see Walter et al. (2006).

Water samples for $\delta^{15} \mathrm{~N}$ nitrate and nitrite analysis were collected in $125 \mathrm{ml}$ HDPE bottles and kept frozen prior to analysis. For logistical reasons, samples from the M77 cruise that contained low to negligible levels of nitrite $\left(\left[\mathrm{NO}_{2}^{-}\right]<0.1 \mu \mathrm{mol} 1^{-1}\right)$ were acidified and stored at room temperature, whereas samples with significant $\left[\mathrm{NO}_{2}^{-}\right]$were kept frozen prior to the $\delta^{15} \mathrm{~N}-\mathrm{NO}_{2}^{-}$analysis. Aliquots of these samples were treated in the laboratory with sufficient sulfanilic acid to remove $\left[\mathrm{NO}_{2}^{-}\right]$prior to $\delta^{15} \mathrm{~N}^{-\mathrm{NO}_{3}^{-}}$analysis with any remaining sample stored at room temperature.

The isotopic composition of dissolved nitrate $\left(\delta^{15} \mathrm{~N}\right.$ $\left.\mathrm{NO}_{3}^{-}\right)$and nitrite $\left(\delta^{15} \mathrm{~N}-\mathrm{NO}_{2}^{-}\right)$was measured using the $\mathrm{Cd}-$ reduction/azide method (McIlvin and Altabet, 2005) with addition of $\mathrm{NaCl}$ as described by Ryabenko et al. (2009). All the samples from the Atlantic study region and $50 \%$ of the Pacific samples were analyzed at the IFM-GEOMAR in Germany, while c. $50 \%$ of the Pacific samples were analyzed at SMAST in the USA, using the same method. The only difference was that at SMAST $\mathrm{N}_{2} \mathrm{O}$ produced by this method was analyzed isotopically, whereas at IFM-GEOMAR $\mathrm{N}_{2} \mathrm{O}$

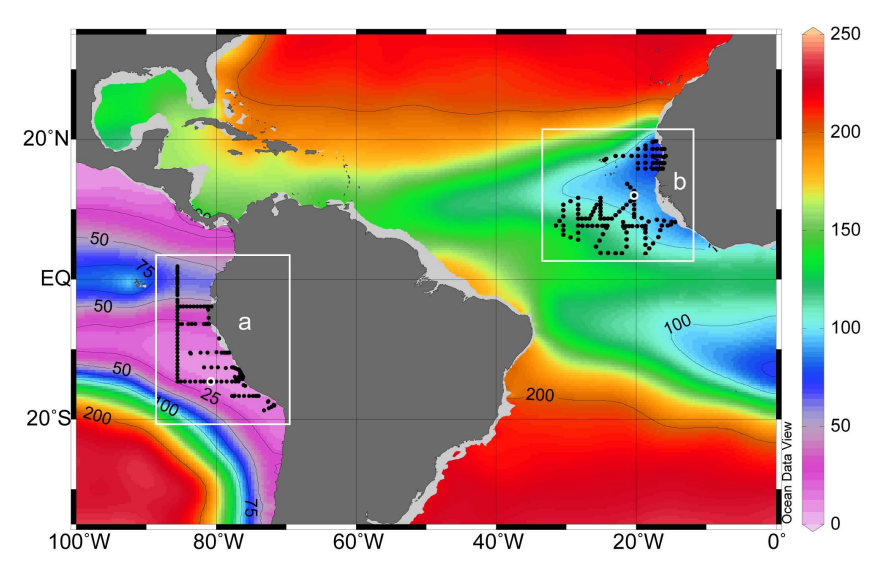

Fig. 1. Oxygen distribution at $200 \mathrm{~m}$ (Schlitzer, R., Ocean Data View, World Ocean Atlas 2005, http://odv.awi.de/en/data/ocean/ world_ocean_atlas_2005/) with CTD station locations in the Pacific (a) and Atlantic (b) study regions referred to in the text. White circles indicate station 84 (a) and station 5 (b).

was converted on-line to $\mathrm{N}_{2}$ for isotopic analysis. The detection limit at IFM-GEOMAR was $0.2 \mu \mathrm{mol} \mathrm{l}^{-1}$ of nitrate or nitrite with the precision of the $\delta^{15} \mathrm{~N}$ measurements being $\pm 0.2 \%$. The detection limit at SMAST was slightly higher, $0.5 \mu \mathrm{mol} 1^{-1}$, with the same precision of ${ }^{15} \mathrm{~N}$ measurements.

The analyses of the Pacific deep water samples $(>1500 \mathrm{~m})$ from both labs gave near identical values of $\delta^{15} \mathrm{~N}-$ $\left(\left[\mathrm{NO}_{2}^{-}\right]+\left[\mathrm{NO}_{3}^{-}\right]\right)$of $5.69 \pm 0.7 \%$ (IFM-GEOMAR; $\left.n=31\right)$ and $5.62 \pm 0.4 \%$ (SMAST; $n=8$ ) respectively. The Fisher test showed that we can merge the two data sets with a confidence level $>95 \%$. The resulting mean value of $5.64 \pm 0.7 \%$ o $(n=39)$ lies between previously published values of $6.5 \%$ Voss (2001) and 4.5\% Sigman (1997) for the deep North Pacific Ocean. Deep waters of the Atlantic showed very similar values as those of the Pacific $(5.3 \% \circ \pm 0.5$ for $>2000 \mathrm{~m}$, see Supplementary material, Table 1).

\section{Hydrographic setting of the two study regions}

In the North Equatorial Atlantic region, the eastward flow of the North Equatorial Counter Current (NECC) and North Equatorial Under Current (NEUC) supplies oxygen rich waters to the Atlantic OMZ (Glessmer et al., 2009). The water mass distribution in this Atlantic OMZ study region (Fig. 1b) is affected by the Cape Verde Frontal Zone, which marks the boundary between North and South Atlantic Central Waters (NACW, SACW). This separates well-ventilated waters of the subtropical gyre in the north from less-ventilated waters to the south. Our CTD data (Fig. 2) show water mass properties $<500 \mathrm{~m}$ intermediate between those of NACW and SACW. Antarctic Intermediate Water (AAIW: $3-5^{\circ} \mathrm{C}$, $S=34.5$ ) is found at $\sim 1000 \mathrm{~m}$ with North Atlantic Deep Water (NADW) filling the depth range between $\sim 1000$ and 
Table 1. Predicted surface water $\delta^{15} \mathrm{~N}-N O_{3}^{-}$under different scenarios. $\mathrm{F}_{\text {total }}=\mathrm{F}_{\text {dust }}+\mathrm{F}_{\text {mixing }}-\mathrm{F}_{\text {assimilation. The end members for } \delta}{ }^{15} \mathrm{~N}$ surface water calculation were: $\delta^{15} \mathrm{~N}$-dust $=-7 \%$ o, $\delta^{15} \mathrm{~N}$-mixing $=5 \%$ and $\delta^{15} \mathrm{~N}$-assimilation $=-5 \%$.

\begin{tabular}{|c|c|c|c|c|}
\hline scenario & $\begin{array}{c}\delta^{15} \mathrm{~N}^{-\mathrm{NO}_{3}^{-}} \text {surface } \\
\text { water }\end{array}$ & $\mathrm{F}_{\text {dust }} / \mathrm{F}_{\text {total }}, \%$ & $\mathrm{~F}_{\text {mixing }} / \mathrm{F}_{\text {total }}, \%$ & $\mathrm{~F}_{\text {assimilation }} / \mathrm{F}_{\text {total }}, \%$ \\
\hline 1 & -5.8 & 90 & 10 & 0 \\
\hline 2 & -1 & 50 & 50 & 0 \\
\hline 3 & 1 & $33 \%$ & $33 \%$ & $33 \%$ \\
\hline
\end{tabular}
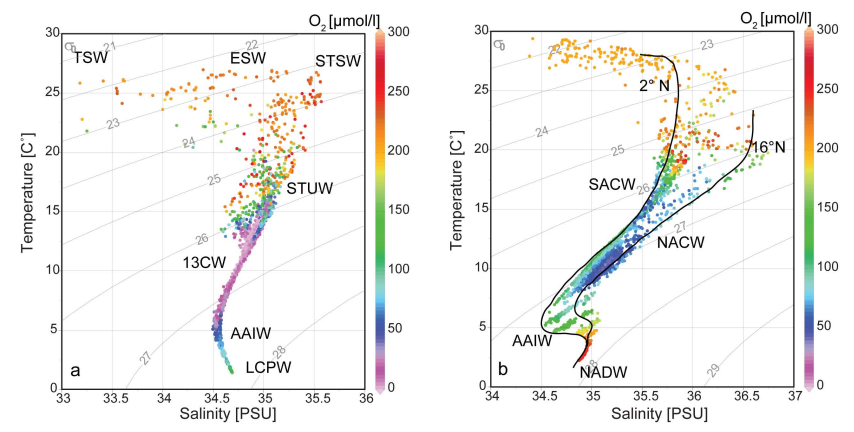

Fig. 2. T-S diagrams with $\mathrm{O}_{2}$ color coded for the Pacific (a) and the Atlantic (b) study regions from CTD data collected during the M77, M80 and L'Atalante cruises.

$4000 \mathrm{~m}$ (Fig. 2b). A summary of the water masses properties found in both study regions is presented in Supplementary material, Table 1.

In the South Pacific, the Equatorial Undercurrent (EUC), Southern Subsurface Counter Currents (SCCs), and the Southern Intermediate Counter Currents (SICC) supply $13{ }^{\circ} \mathrm{C}$ Equatorial Water $\left(13 \mathrm{CW}, 25.8<\sigma_{\theta}<26.6\right)$ to the eastern Pacific OMZ (Stramma et al., 2010). The westward flowing South Equatorial Current (SEC) may recirculate some $13^{\circ}$ water from the $\mathrm{OMZ}$ by returning eastward as the South Subsurface Counter Current at $3-5^{\circ} \mathrm{S}$ (Schott et al., 2004). The origin of $13 \mathrm{CW}$ is remote from the equator $(\mathrm{Qu}$ et al., 2009) mostly as Subantarctic Mode Water (SAMW; (Toggweiler et al., 1991)) and transports very oxygen depleted waters to the OMZ, due to its relative old age. The South $\mathrm{Pa}$ cific Subtropical Underwater (STUW) is a likely $\mathrm{O}_{2}$ source from the south which is centered on the $\sigma_{\theta}=25.0$ isopycnal and is well-ventilated across nearly the full width of the subtropical gyre (O'Connor et al., 2002). The low-salinity water $(\mathrm{S}<34.5)$ found between c. 500 and $1000 \mathrm{~m}$ southward of $10^{\circ} \mathrm{S}$ is Antarctic Intermediate Water (AAIW). South Pacific Deep Water $\left(1.2-2{ }^{\circ} \mathrm{C}\right)$ is found between c. $1500-3000 \mathrm{~m}$ and is underlain by Lower Circumpolar Water (LCPW) (Fiedler and Talley, 2006) (Fig. 2a).

Because of the differences in hydrography and significantly lower oxygen supply, the Pacific OMZ is much
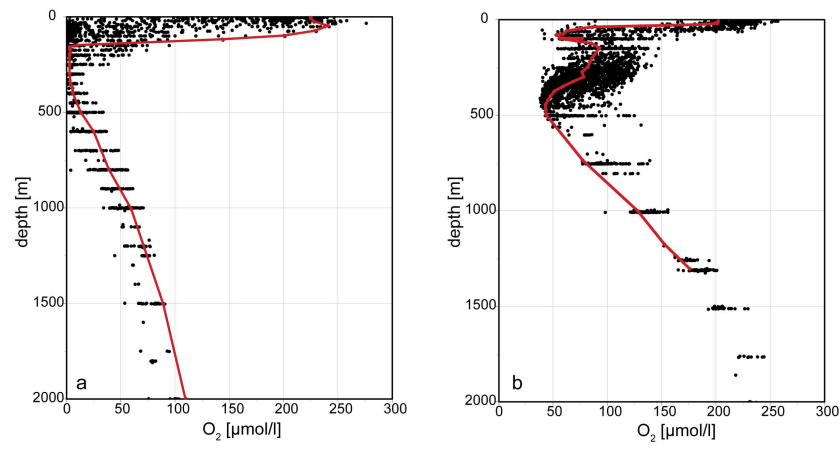

Fig. 3. Oxygen distribution in the Pacific (a) and the Atlantic (b) study regions, as measured on the cruises M77, M80 and L'Atalante. The red lines show the water-column profiles for M77 station 84 in the Pacific and M80 station 5 in the Atlantic

more intense as compared to the Atlantic (Karstensen et al., 2008). The resulting very low oxygen concentrations favor metabolic pathways that convert nitrogen from biologically reactive "fixed" forms (for example nitrate, nitrite or ammonium) to $\mathrm{N}_{2}$ via denitrification and/or anammox.

\section{Results and discussion}

\subsection{Vertical distribution of nitrogen species and isotopes}

\subsubsection{General}

Dissolved $\mathrm{O}_{2}$ varies considerably in its depth distribution between the Atlantic and Pacific study regions as shown in Fig. 3. Figure 4 presents typical water column profiles for oxygen and several nitrogen related properties from both study regions (outside of the upwelling zones). Stations 5 (Atlantic, M80) and 84 (Pacific, M77) were chosen due to synoptic availability of $\mathrm{N}_{2} \mathrm{O}, \delta^{15} \mathrm{~N}$ and $\left[\mathrm{NO}_{2}^{-}\right]$data. The geographic positions of the stations are indicated on Fig. 1 by white circles. 

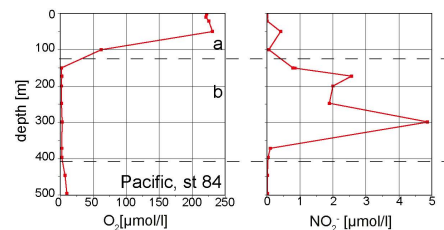

$\mathrm{NO}_{2}[\mu \mathrm{mol} / \mathrm{l}]$
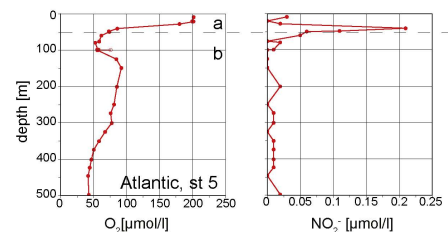

$\mathrm{NO}_{2}[\mathrm{\mu mol} / \mathrm{l}]$

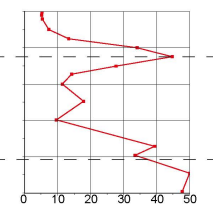

$\mathrm{N}_{2} \mathrm{O}[\mathrm{nmol} / \mathrm{l}]$

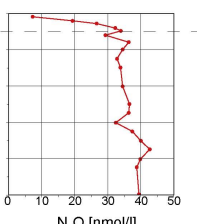

$\mathrm{N}_{2} \mathrm{O}[\mathrm{nmol} / \mathrm{l}]$
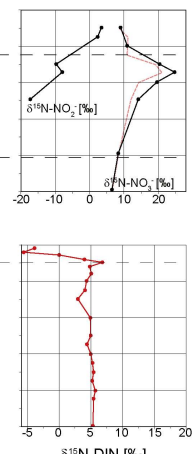

$8^{15} \mathrm{~N}-\mathrm{DIN}[\%]$
Fig. 4. Typical water column profiles from the SE Pacific OMZ (st. $84,81^{\circ} \mathrm{W} / 14^{\circ} \mathrm{S}$ ) from the M77 cruise (upper panels) and the $\mathrm{NE}$ Atlantic $\mathrm{OMZ}$ (st. 5, 20.5 ${ }^{\circ} \mathrm{W} / 12.3^{\circ} \mathrm{N}$ ) from the M80 cruise (lower panels). Black lines in the Pacific indicate $\delta^{15} \mathrm{~N}^{-\mathrm{NO}_{3}^{-}}$and $\delta^{15} \mathrm{~N}-\mathrm{NO}_{2}^{-}$, and the red line indicates $\delta^{15} \mathrm{~N}$-DIN (calculated as the concentration weighed average of the $\mathrm{NO}_{3}^{-}$and $\mathrm{NO}_{2}^{-} \quad \delta^{15} \mathrm{~N}$ values). Note the different of scales for $\delta^{15} \mathrm{~N}:-20$ to $+20 \%$ in the Pacific and -5 to $+20 \%$ in the Atlantic.

\subsubsection{Pacific study region}

In the Pacific study region, the OMZ contains mostly $13 \mathrm{CW}$, with oxygen concentrations $<2 \mu \mathrm{moll}^{-1}$ at depths as shallow as $\sim 50 \mathrm{~m}$ and as deep as $\sim 550 \mathrm{~m}$. The Pacific station (Fig. 4, upper panels) is also characterized by a broad oxygen minimum with $\left[\mathrm{O}_{2}\right]<2 \mu \mathrm{moll}^{-1}(170-400 \mathrm{~m})$. We divide the Pacific profile into layers (a) and (b) to focus the discussion of nitrogen transformations at the upper OMZ boundary and its core.

Layer a $(0-120 \mathrm{~m})$ includes a $\sim 70 \mathrm{~m}$ deep mixed layer and the $50 \mathrm{~m}$ deep euphotic zone (Chavez and Messie, 2009), and contains water with the highest oxygen concentrations as well as a very sharp oxycline at $80-120 \mathrm{~m}$ in which $\left[\mathrm{O}_{2}\right]$ drops from $\sim 150$ to $20 \mu \mathrm{moll}^{-1}$. The primary nitrite maximum lies close to the base of the euphotic zone and can be a consequence of two processes (Lomas and Lipschultz, 2006): light-limited, incomplete assimilatory reduction of nitrate by phytoplankton and microbial ammonium oxidation to nitrite (i.e. the first step of nitrification). Near-surface $\mathrm{N}_{2} \mathrm{O}$ is close to saturation and increases within the oxycline from $\sim 12$ to $\sim 45 \mathrm{nmol}^{-1}$. The observed increase in nitrous oxide within the oxycline can be associated with ammonia oxidation (Codispoti, 2010), which leads to an efflux of $\mathrm{N}_{2} \mathrm{O}$ from the mixed layer to the atmosphere via gas exchange. The concentrations of $\left[\mathrm{NO}_{3}^{-}\right]$and $\left[\mathrm{NO}_{2}^{-}\right]$above $80 \mathrm{~m}$ in layer a at this station were below our detection limit for $\delta^{15} \mathrm{~N}$ measurement $\left(0.2 \mu \mathrm{mol}^{-1}\right)$. Higher near-surface DIN concentrations were observed at other stations along the $86^{\circ} \mathrm{W}$ transect and the corresponding $\delta^{15} \mathrm{~N}^{-\mathrm{NO}_{3}^{-}}$values were as high as $20 \%$. High surface $\delta^{15} \mathrm{~N}^{-\mathrm{NO}_{3}^{-}}$is likely the result of incomplete nutrient utilization and fractionation during nitrate assimilation (Granger et al., 2004). $\delta^{15} \mathrm{~N}-\mathrm{NO}_{2}^{-}$is generally much lower than $\delta^{15} \mathrm{~N}-\mathrm{NO}_{3}^{-}$and the difference between the two increases from layer a to layer b. Relative ${ }^{15} \mathrm{~N}$ depletion in nitrite can be explained by isotopic fractionation during nitrate reduction to nitrite. A smaller difference between $\delta^{15} \mathrm{~N}_{-} \mathrm{NO}_{3}^{-}$and $\delta^{15} \mathrm{~N}^{-\mathrm{NO}_{2}^{-}}$observed in the oxycline is likely due to nitrification as the fractionation effect of the process is significantly smaller $(\sim 13 \%$ o) (Casciotti, 2009; Casciotti and McIlvin, 2007) then the one expected for denitrification ( 25\% ) (Barford, 1999; Granger, 2006). Thus there is evidence for a clear switch from nitrification to denitrification with depth.

Layer b (120m to $400 \mathrm{~m})$. $\mathrm{O}_{2}$ concentrations in this layer drop below $5 \mu \mathrm{moll}^{-1}$ and there is a strong increase in $\left[\mathrm{NO}_{2}^{-}\right]$towards a "secondary" maximum at the core of OMZ. $\mathrm{N}_{2} \mathrm{O}$ concentrations drop sharply within the OMZ core to $\sim 10 \mathrm{nmol}^{-1}$ and increase again only towards the lower border of the layer. Denitrification is the only N-removal process which is known to consume $\mathrm{N}_{2} \mathrm{O}$, hence it is likely that both the increase in $\left[\mathrm{NO}_{2}^{-}\right]$and the increase and decrease in $\left[\mathrm{N}_{2} \mathrm{O}\right]$ within this layer can be attributed to different stages of canonical denitrification $\left(\mathrm{NO}_{3}^{-} \rightarrow \mathrm{NO}_{2}^{-} \rightarrow \mathrm{N}_{2} \mathrm{O} \rightarrow \mathrm{N}_{2}\right.$ ) (Bange, 2008). The vertical profiles, especially the minimum in $\mathrm{N}_{2} \mathrm{O}$ within the OMZ's core, provide strong evidence that all stages of canonical denitrification influence nitrogen speciation in this layer. The observed increase in $\delta^{15} \mathrm{~N}_{-} \mathrm{NO}_{3}^{-}$ and decrease in $\delta^{15} \mathrm{~N}^{-\mathrm{NO}_{2}^{-}}$at the base of the layer B are also consistent with denitrification, which leaves $\left[\mathrm{NO}_{2}^{-}\right]$depleted in ${ }^{15} \mathrm{~N}$. Interestingly, the difference between $\delta^{15} \mathrm{~N}-\mathrm{NO}_{3}^{-}$and

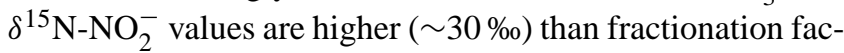
tor calculated for N-loss process within OMZ $(\sim 11.4 \%$, see below) but close to the expected value for pure culture studies $(28.6 \%$ ) (i.e. Barford et al., 1999). The reason for this could be the nitrite oxidation, which has an inverse isotopic fractionation effect, leaving $\delta^{15} \mathrm{~N}^{-\mathrm{NO}_{2}^{-}}$depleted in ${ }^{15} \mathrm{~N}$ (Casciotti, 2009). Nitrite oxidation can appear in nitrificationdenitrification coupled systems or in anammox as a sidereaction (i.e. Straus 1998, van de Graaf 1996). The deep $\left[\mathrm{NO}_{2}^{-}\right]$maximum can support anammox, which has been observed in several previous studies of this region (Galan et al., 2009; Hamersley et al., 2007; Lam et al., 2009).

\subsubsection{Atlantic study region}

In the Atlantic study region, the oxygen profile has two minima at $\sim 70 \mathrm{~m}$ and $\sim 400 \mathrm{~m}$ (Fig. 3b). The shallow minimum is strongest between Senegal and the Cape Verde Islands and is probably caused by enhanced subsurface remineralization associated with high biological productivity and a shallow mixed layer (Karstensen et al., 2008). The deeper minimum is more prominent south of Cape Verde and is associated with the water mass boundary between Central Water and AAIW (Stramma et al., 2005). The double oxygen minimum (Fig. 3 ) is therefore caused by the mixing of two water masses from the North and South (NACW and SACW) of the Atlantic region. 


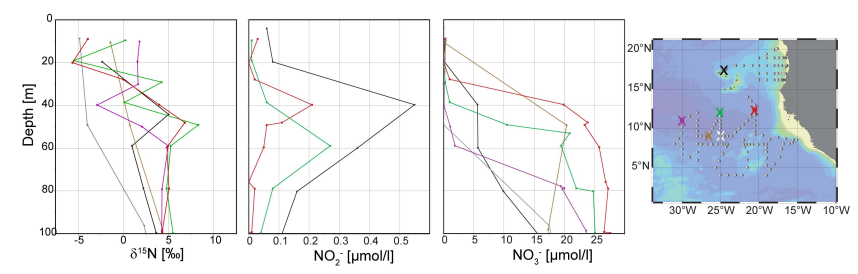

Fig. 5. Shallow vertical profiles of M80 stations south to Cape Verde islands in the Atlantic. Stations: 1 (TENATSO) and 5, 67, 76,81 and 87 located between $12^{\circ} \mathrm{N}$ and $9^{\circ} \mathrm{N}$.

The profiles from the Atlantic station (Fig. 4, lower panels) are considerably simpler, with fewer subsurface features. Once again, two layers have been distinguished based on oxygen concentration and its influence on dominant nitrogen cycle processes.

Layer a $(0-50 \mathrm{~m})$ includes the surface mixed layer which extends to c. $30 \mathrm{~m}$. This layer includes the steepest part of the oxycline, a strong increase in $\mathrm{N}_{2} \mathrm{O}$ with depth, and a primary nitrite maximum which lies at the base of this layer. The $\delta^{15} \mathrm{~N}$ of DIN increases steadily throughout this layer and reaches a maximum at a depth close to the primary nitrite maximum. These features can be attributed to a combination of remineralization of organic matter, nitrite excretion by phytoplankton after nitrate reduction and nitrification. In contrast to the Pacific study region, the surface layer has minimum values of $\delta^{15} \mathrm{~N}$ in DIN, with some values being strongly negative (e.g. $-5.6 \%$ at $20 \mathrm{~m}$ ).

Examination of near-surface profiles from the Atlantic (Fig. 5) reveals negative values of $\delta^{15} \mathrm{~N}$ in DIN within the surface mixed layer at stations located South of Cape Verde and at the TENATSO station. There is a tendency for the values to be most negative at the shallowest depths $(20 \mathrm{~m})$ with extremely low $\delta^{15} \mathrm{~N}$ values almost always observed in this depth range. Generally below $20 \mathrm{~m}$, both $\mathrm{NO}_{3}^{-} \delta^{15} \mathrm{~N}$ and concentration increase with depth. We argue that the source of nitrate at the very surface of stations with low $\delta^{15} \mathrm{~N} \mathrm{NO}_{3}^{-}$is from atmospheric deposition (see below, Sect. 4.2.5). Nitrite concentration was below the detection limit of $0.02 \mu \mathrm{moll}^{-1}$, while $\left[\mathrm{NO}_{3}^{-}\right]$concentrations in the region are about $0.1-$ $0.5 \mu \mathrm{moll} \mathrm{l}^{-1}$. Thus contamination via nitrite cannot be the reason for low $\delta^{15} \mathrm{~N}$ values. In regions more influenced by upwelled waters, the near-surface values were higher in the range $+4-+7 \%$ and more consistent with an isotopic signal from upwelled $\mathrm{NO}_{3}^{-}$. Even though these concentration levels lie close to our detection limit for $\delta^{15} \mathrm{~N}$ measurements $\left(0.2 \mu \mathrm{mol} \mathrm{l}^{-1}\right)$, all surface water samples were measured 5 times and gave reliable values with $>95 \%$ reliability and $\pm 0.3 \%$ o standard deviation. Further, laboratory tests with dilutions of $\delta^{15} \mathrm{~N}$ standards showed no suggestion of any systematic change of measured $\delta^{15} \mathrm{~N}$ values with decreasing $\left[\mathrm{NO}_{3}^{-}\right]$concentrations.
Apparent exceptions are found at stations 87 at $25^{\circ} \mathrm{W}$ and 67 at $30^{\circ} \mathrm{W}$ (marked with white and purple crosses in Fig. 5) where low $\delta^{15} \mathrm{~N}$ of -4 and $-3 \%$ are observed at 50 and $40 \mathrm{~m}$ respectively. Corresponding nitrate concentrations are 0.25 and $0.20 \mu \mathrm{mol} \mathrm{l}^{-1}$, respectively, and nitrite concentration is below the detection limit. While these values appear to be too deep to be influenced by atmospheric input, in fact the mixed layer is indeed deeper at these stations: $40-50 \mathrm{~m}$ instead of $20 \mathrm{~m}$. Thus, we believe, that the low $\delta^{15} \mathrm{~N}$ signal at these stations could also originate from atmospheric deposition. To be conservative, we only considered the upper $20 \mathrm{~m}$ water column for our calculations of nitrogen fluxes in the Table 1 (see Sect. 4.2.5).

At station 1 (TENATSO, marked with black cross in Fig. 5) between $40-60 \mathrm{~m}$ isotope signature lay $0<\delta^{15} \mathrm{~N}<5$ with nitrate concentrations increasing up to $6 \mu \mathrm{mol} 1^{-1}$ and nitrite up to $0.55 \mu \mathrm{moll}^{-1}$. Elevated nitrate and nitrite concentrations having a $\delta^{15} \mathrm{~N}$ signature of only few per mil is here likely due to $\mathrm{N}$-fixation, which was observed in this region during other studies (i.e. Bourbonnais 2009).

Layer $b$ (below $50 \mathrm{~m}$ ) includes the core of the Atlantic OMZ. In contrast to the Pacific OMZ, the Atlantic profiles had no secondary nitrite maximum, and $\delta^{15} \mathrm{~N}$ values and $\mathrm{N}_{2} \mathrm{O}$ concentrations remained relatively constant with depth. The $\mathrm{N}_{2} \mathrm{O}$ profiles show no evidence for consumption as was seen in the Pacific. This is a clear indication for the absence of significant denitrification in this region. A slight increase in $\mathrm{N}_{2} \mathrm{O}$ with depth below $50 \mathrm{~m}$ can be explained by nitrification (Walter et al., 2006).

\subsection{Property-property distributions}

\subsubsection{Nitrate to Phosphate}

Figure 6 presents the $\mathrm{NO}_{3}^{-}$to $\mathrm{PO}_{4}^{3-}$ relationship (with dissolved oxygen concentrations as the color code) for the Atlantic and Pacific study regions. According to Redfield stoichiometry, the average ocean ratio of $\mathrm{N}: \mathrm{P}$ is $16: 1$. Deviations from this ratio can be an indicator for which nutrient sink/source processes are dominating in the ocean region of interest. Waters in the Pacific study region are highly Ndeficient $(\mathrm{N}: \mathrm{P}<16)$, with the highest deficits found in oxygen minimum waters (purple coloring, Fig. 6a) and associated with the N-removal processes denitrification and/or anammox (Deutsch et al., 2001). Data from the Atlantic study region show strong positive deviations from the 16:1 Redfield stoichiometry, which can be a result of $\mathrm{N}_{2}$-fixation (Hansell et al., 2004; Michaels et al., 1996; Gruber and Sarmiento, 1997) and/or nutrient uptake and/or remineralization with non-Redfield stoichiometry (Monteiro and Follows, 2006). Positive deviations from Redfield stoichiometry can also, potentially, be caused by atmospheric deposition of nitrogen (Duce et al., 2008). Note that our treatment of deviations in $\left[\mathrm{NO}_{3}^{-}\right]:\left[\mathrm{PO}_{4}^{3-}\right]$ does not include the nitrite $\left(\mathrm{NO}_{2}^{-}\right)$produced under low oxygen. Including $\mathrm{NO}_{2}^{-}$in the calculation, 

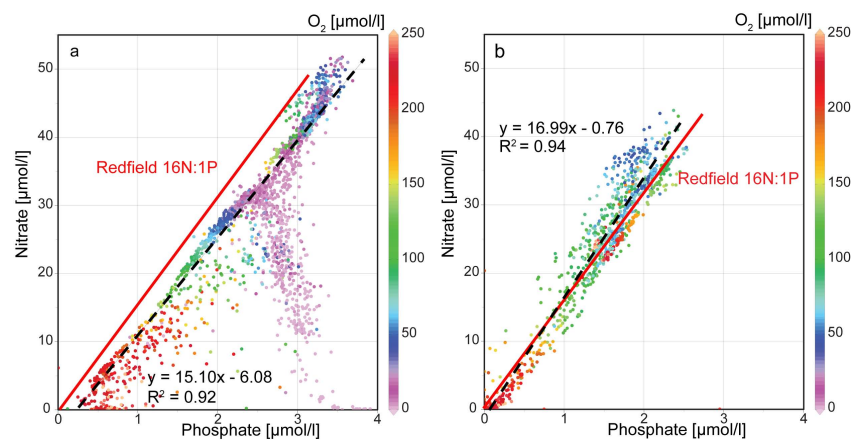

Fig. 6. $\left[\mathrm{NO}_{3}\right]:\left[\mathrm{PO}_{4}\right]$ relationships in the Pacific (a) and the Atlantic (b) study regions. The data are color-coded by oxygen concentration. Note that the average $\left[\mathrm{NO}_{3}\right]:\left[\mathrm{PO}_{4}\right]$ relationship in the Pacific was calculated for $\left[\mathrm{O}_{2}\right]>50 \mu \mathrm{mol} 1^{-1}$.
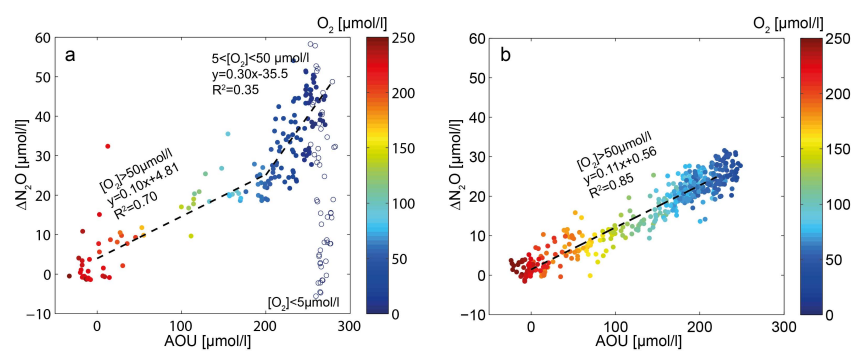

Fig. 7. $\Delta \mathrm{N}_{2} \mathrm{O}$ vs. AOU at upper oxycline $(350 \mathrm{~m}$ in the Pacific (a) and $500 \mathrm{~m}$ the Atlantic (b) study areas) with oxygen concentration as color code. Black dashed lines show the correlation between $\Delta \mathrm{N}_{2} \mathrm{O}$ and AOU, empty circles indicate the samples with $\left[\mathrm{O}_{2}\right]<5 \mu \mathrm{moll}^{-1}$.

however, does not change the ratios significantly (average DIN: $\left[\mathrm{PO}_{4}^{3-}\right]=15.04$ in the Pacific and 16.92 in the Atlantic regions).

\subsection{2 $\quad \mathrm{N}_{2} \mathrm{O}$ vs. $\mathrm{AOU}$}

Property-property plots of $\Delta \mathrm{N}_{2} \mathrm{O}$ to apparent oxygen utilization (AOU) (with $\left[\mathrm{O}_{2}\right]$ as the color code) are presented in Fig. 7, where AOU is the difference between the measured dissolved oxygen concentration and its equilibrium concentration in water with the same physical and chemical properties.

$\Delta \mathrm{N}_{2} \mathrm{O}$ is the excess nitrous oxide and is defined as the difference between the measured $\mathrm{N}_{2} \mathrm{O}$ and the equilibrium $\mathrm{N}_{2} \mathrm{O}$ concentration at the time when a water parcel had its last contact with the atmosphere. Because the atmospheric $\mathrm{N}_{2} \mathrm{O}$ mixing ratios have been increasing since 1800, the calculation of excess $\mathrm{N}_{2} \mathrm{O}$ has to take into account the age of the water parcel at the time of the measurement. Freing et al. (2009) showed that the difference in the slopes of $\Delta \mathrm{N}_{2} \mathrm{O}$ vs. AOU associated with different ways of calculating excess $\mathrm{N}_{2} \mathrm{O}$ can be as much as $17 \%$. The methods used include the transit time distribution (TTD) approach, where CFC-12 and $\mathrm{SF}_{6}$ data are used to calculate a mean-age of a water parcel. Alternatively, a "layer" method (Walter et al., 2004) uses different equilibrium $\mathrm{N}_{2} \mathrm{O}$ concentrations for mixed layer and deep waters. For the sake of simplicity we used here the "contemporary" approach, where the $\left[\mathrm{N}_{2} \mathrm{O}\right]_{\mathrm{eq}}$ in the upper $500 \mathrm{~m}$ is calculated based on the contemporary atmospheric dry mole fraction of $\mathrm{N}_{2} \mathrm{O}\left(\mathrm{N}_{2} \mathrm{O}\right.$ of $322 \times 10^{-9}$ for Pacific data and $323 \times 10^{-9}$ for Atlantic data, http://agage.eas.gatech.edu/) (Nevison et al., 2003; Yoshinari, 1976). Although the contemporary method may lead to underestimations of $\Delta \mathrm{N}_{2} \mathrm{O}$ vs. AOU slopes of up to $17 \%$ (Freing et al., 2009), it does not affect the qualitative comparison of the Atlantic and $\mathrm{Pa}$ cific study regions given below. An overall linear relationship of $\Delta \mathrm{N}_{2} \mathrm{O}$ to AOU (Fig. 7) was observed previously in both regions (Oudot et al., 1990; Elkins et al., 1978; Nevison et al., 2003).

However, the Pacific relationship has two different slopes for oxygen concentrations below and above $50 \mu \mathrm{mol} 1^{-1}$ (which corresponds here to an AOU of c. $208 \mu \mathrm{moll}^{-1}$ ). For $5<\left[\mathrm{O}_{2}\right]<50 \mu \mathrm{moll}^{-1}$ the slope of the $\Delta \mathrm{N}_{2} \mathrm{O}$ to AOU relation is $0.30 \pm 0.050$ which is significantly higher than that for $\left[\mathrm{O}_{2}\right]>50 \mu \mathrm{moll}^{-1}(0.10 \pm 0.009)$. This is suggestive of a higher yield of $\mathrm{N}_{2} \mathrm{O}$ per mole $\mathrm{NO}_{3}^{-}$produced by nitrification at low oxygen levels (Goreau et al., 1980; Stein and Yung, 2003). In Pacific waters with $\left[\mathrm{O}_{2}\right]<5 \mu \mathrm{mol}^{-1}$ (AOU of c. $248 \mu \mathrm{moll}^{-1}$ ), $\Delta \mathrm{N}_{2} \mathrm{O}$ concentrations decrease again to near-zero values, indicative of the consumption of $\mathrm{N}_{2} \mathrm{O}$ at very low oxygen levels mentioned above. Corresponding changes in slope are not visible in the Atlantic data, likely because there are so few data with $\left[\mathrm{O}_{2}\right]<50 \mu \mathrm{moll}^{-1}$. The slopes of the $\Delta \mathrm{N}_{2} \mathrm{O}$ vs. AOU relationships for $\left[\mathrm{O}_{2}\right]>50 \mu \mathrm{moll}^{-1}$ are remarkably similar in both regions: $0.10 \pm 0.009$ and $0.11 \pm 0.003$ in the Pacific and Atlantic, respectively. These values lie close to the value of 0.107 reported for the tropical Atlantic by Walter et al. (2006) but lower than the value of 0.211 reported by Oudot (2002). The values from the Oudot (2002) paper, however, should be taken with particular care as the mean atmospheric mixing ratio of $\mathrm{N}_{2} \mathrm{O}$ presented in their paper $\left(316 \times 10^{-9}\right)$ seems to be unrealistically high in comparison to the mean atmospheric background dry mole fraction of $\mathrm{N}_{2} \mathrm{O}$ at the time of their measurements $\left(308 \times 10^{-9}\right.$, http://agage.eas.gatech.edu/).

This higher yield of $\mathrm{N}_{2} \mathrm{O}$ under reduced concentrations of oxygen was observed earlier (Goreau et al., 1980) and was attributed to increasing $\mathrm{N}_{2} \mathrm{O}$ yield when ammonia oxidizing microbes become $\mathrm{O}_{2}$ stressed. This view was challenged by Frame and Casciotti (2010), who showed that ammonia-oxidizing bacteria do not have increased $\mathrm{N}_{2} \mathrm{O}$ yield under low $\mathrm{O}_{2}$ conditions under environmentally relevant culture conditions. The most recent findings from both the Atlantic and Pacific oceans indicate however that archaeal ammonia-oxidizers (AOA) rather than bacteria may be key organisms for the production of oceanic nitrous oxide and 
can exhibit higher production rates under low oxygen conditions (Löscher et al., 2011).

Regarding the Pacific observations at very low $\mathrm{O}_{2}, \mathrm{~N}_{2} \mathrm{O}$ removal provides strong evidence for the occurrence of denitrification given its specificity for this process (Bange et al., 2005). However, the amount of $\mathrm{N}_{2} \mathrm{O}$ removed (c. $50 \mathrm{nmoll}^{-1}$ ) is an order of magnitude lower than the observed amount of $\mathrm{NO}_{3}^{-}$removal. Hence it gives no indication of the quantitative significance of this process for overall fixed nitrogen removal (e.g. compared to anammox).

Additional insight into $\mathrm{N}$-loss processes is gained here from nitrogen isotope $\left(\delta^{15} \mathrm{~N}-\mathrm{NO}_{3}^{-}\right)$and fixed nitrogen deficit (N') data.

\subsection{3 $\delta^{15} \mathrm{~N}-\mathrm{NO}_{3}^{-}$vs. $\mathrm{N}_{2} \mathrm{O}$ and $\mathrm{N}^{\prime}$}

Figure 8 shows $\Delta \mathrm{N}_{2} \mathrm{O}$ vs. $\delta^{15} \mathrm{~N}-\mathrm{NO}_{3}^{-}$(with color coding indicating oxygen concentration) in the two study regions, which helps to reveal processes responsible for the production or consumption of nitrous oxide. In the Atlantic, the profiles and property-property plots show no evidence of $\mathrm{N}_{2} \mathrm{O}$ consumption and the nitrogen isotope values stay close to the oceanic average of $5 \%$, which is also consistent with a lack of denitrification. As discussed above, the dominant process affecting $\mathrm{N}_{2} \mathrm{O}$ in the Atlantic study region is production due to nitrification. For Pacific oxygenated waters $\left(\left[\mathrm{O}_{2}\right]>5 \mu \mathrm{moll}^{-1}\right)$ the $\Delta \mathrm{N}_{2} \mathrm{O}$ vs. $\delta^{15} \mathrm{~N}^{-\mathrm{NO}_{3}^{-}}$relationship is similar to that found in the Atlantic. The reason for some very low $\delta^{15} \mathrm{~N}_{-} \mathrm{NO}_{3}^{-}$values in Atlantic surface water is discussed below. A trend towards high $\delta^{15} \mathrm{~N}^{-N^{-}} \mathrm{O}_{3}^{-}$values in the Pacific study region (Fig. 8a) can be associated with denitrification at lower $\mathrm{O}_{2}$ concentrations $\left(\left[\mathrm{O}_{2}\right]<5 \mu \mathrm{mol}^{-1}\right.$, purple coloring) or with nitrate assimilation in near surface waters $\left(\left[\mathrm{O}_{2}\right]>200 \mu \mathrm{moll}^{-1}\right.$, red coloring). These two processes cannot be distinguished in figure $8 \mathrm{a}$ as the $\Delta \mathrm{N}_{2} \mathrm{O}$ is close to zero both for waters with $\left[\mathrm{O}_{2}\right]<5 \mu_{\mathrm{moll}}{ }^{-1}$ (due to denitrification), and for waters with $\left[\mathrm{O}_{2}\right]>200 \mu \mathrm{moll}^{-1}$ (due to $\mathrm{N}_{2} \mathrm{O}$ equilibration with the atmosphere). In order to differentiate between these two processes the correlation between $\delta^{15} \mathrm{~N}-\mathrm{NO}_{3}^{-}$and the N-deficit was calculated (Fig. 8c).

In the core of the OMZ, the $\delta^{15} \mathrm{~N}$ of DIN is inversely correlated with N' (mainly negative values) and hence with $\mathrm{N}$-removal, whereas in high-oxygen, near-surface waters, $\delta^{15} \mathrm{~N}-\mathrm{NO}_{3}^{-}$increases independent of $\mathrm{N}$ ', reflecting fractionation during $\mathrm{NO}_{3}^{-}$assimilation by phytoplankton in the euphotic zone (Granger et al., 2004).

\subsubsection{Isotope fractionation and N-loss in the Pacific OMZ}

The reduction of nitrate to nitrite is the first step of the denitrification process and is also an essential source of $\mathrm{NO}_{2}^{-}$ for fuelling anammox (Lam et al., 2009). We will next examine the isotope fractionation signal associated with this reduction step. The kinetic isotope fractionation factor can

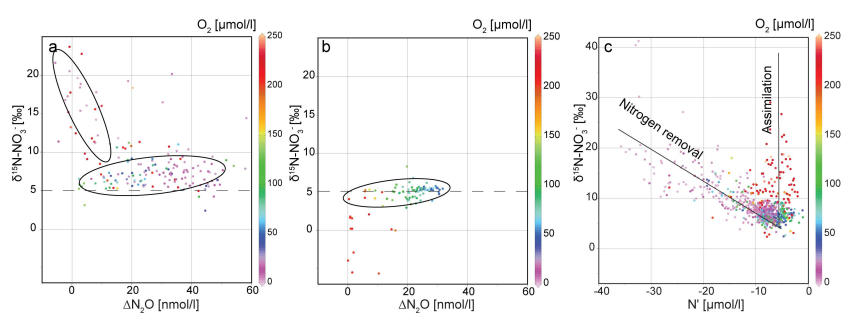

Fig. 8. $\delta^{15} \mathrm{~N}-\mathrm{NO}_{3}^{-}$vs. $\Delta \mathrm{N}_{2} \mathrm{O}$ in the Pacific (a) and in the Atlantic (b) study areas and (c) the $\delta^{15} \mathrm{~N}$ vs. N' distribution in the Pacific. The data are color-coded by oxygen concentration. The nitrogen deficit in the figure $8 \mathrm{c}$ was calculated as $\mathrm{N}^{\prime}=\left[\mathrm{NO}_{3}^{-}\right]+\left[\mathrm{NO}_{2}^{-}\right]-$ $\left.16 \times\left[\mathrm{PO}_{4}^{3-}\right]\right) . \delta^{15} \mathrm{~N}$ vs. $\mathrm{N}^{\prime}$ data reveal two clear trends in the $\mathrm{Pa}-$ cific study region.

be represented as either $\alpha_{r}={ }^{15} \mathrm{R} /{ }^{14} \mathrm{R}$ or $\varepsilon_{\mathrm{r}}=(1-\alpha) \times 1000$, where ${ }^{15} \mathrm{R}$ and ${ }^{14} \mathrm{R}$ are the rates of denitrification for ${ }^{15} \mathrm{NO}_{3}^{-}$ and ${ }^{14} \mathrm{NO}_{3}^{-}$, respectively. An effective or "apparent" value for the fractionation factor for nitrate reduction $\left(\varepsilon_{\mathrm{r}}\right)$ can be calculated through application of the Rayleigh model to the field data or "diffusive" model of Brandes (1998), where diffusive transport is included. Model of Brandes (1998) require knowledge or estimations of denitrification rates and coefficient of eddy diffusivity for fractionation factor calculation. For the Peruvian OMZ neither of those two parameters are known however, thus we calculation $\varepsilon^{*}$ with the Rayleigh model. This model assumes removal from a closed pool of nitrate with constant isotopic fractionation. Hence:

$\delta^{15} \mathrm{~N}-\mathrm{NO}_{3(f)}^{-}=\delta^{15} \mathrm{~N}-\mathrm{NO}_{3(f=1)}^{-}-\varepsilon^{*} \times \ln (f)$,

where $f$ is the fraction of consumed $\mathrm{NO}_{3}^{-}, f=$ $\left[\mathrm{NO}_{3}^{-}\right] /\left(16 \times\left[\mathrm{PO}_{4}^{3-}\right]\right)$, the $\varepsilon^{*}$ is an "apparent" fractionation factor, in this case for a nitrogen removal process. Least squares fitting of all data from the Pacific OMZ (i.e. $\left[\mathrm{O}_{2}\right]<50 \mu \mathrm{moll}^{-1}$ ) is shown in Fig. 10a, with the "apparent" isotopic enrichment factor $\left(\varepsilon^{*}\right)$ estimated to be $+11.4 \%$ (standard error of the fit is 0.7 , Fig. 10). The data are scattered between relationships defined by $\varepsilon^{*}=5$ and $25 \%$ (assuming a common initial value for $\delta^{15} \mathrm{~N}_{\text {initial }}$ of $5.2 \%$ ). This value of $\varepsilon^{*}$ of $+11.5 \%$ is significantly lower than values estimated from data from the Eastern Tropical North Pacific (22.5-30\%o) and Arabian Sea (22-25\%o) (Brandes et al., 1998; Sigman et al., 2003; Voss et al., 2001) and from denitrifier cultures (28.6\%o) (Barford et al., 1999). However the value lies close to a values determined 30 years ago for 2 stations off southern Peru using much less sensitive analytical techniques (13.8\%o) (Liu, 1979).

Separating data for shelf and offshore stations (Fig. 9b) results in fits with significantly different values of $\varepsilon^{*}$ of $7.6 \%$ and $16.0 \%$, respectively. Similar observations of low $\varepsilon_{\mathrm{d}}$ have been made in Santa Barbara Basin as compared to the open ETNP (Sigman et al., 2003). This was attributed to a larger contribution from sedimentary denitrification input 


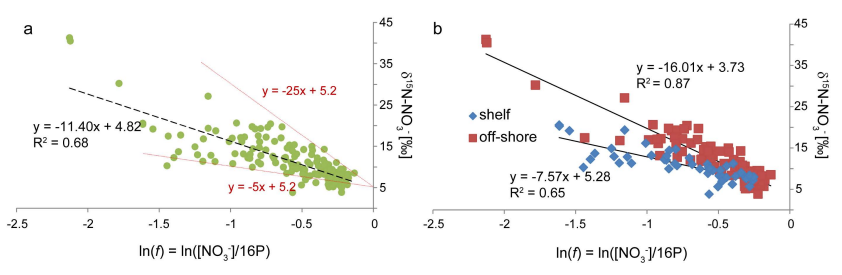

Fig. 9. (a) Application of Rayleigh model to assess fractionation in the Pacific OMZ for all waters with $\left[\mathrm{O}_{2}\right]<50 \mu \mathrm{mol} \mathrm{l}^{-1}$. Dashed lines indicate relationships calculated for $\varepsilon_{\mathrm{d}}=5$ and $25 \%$ o. The average calculated or "apparent" fractionation factor for the entire region is $11.4 \%$ o. (b) Apparent fractionation factors calculated separately for shelf (stations shallower then $200 \mathrm{~m}$ ) and offshore (stations deeper then $200 \mathrm{~m}$ ) stations. The shelf stations show a lower apparent fractionation factor of $7.6 \%$, while the value for off-shore stations is $16.0 \%$.
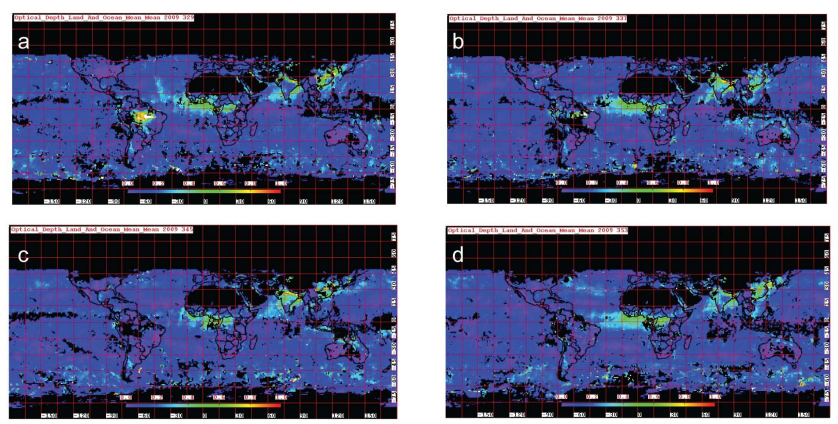

Fig. 10. Satellite images of Aerosol Optical Depth at different time periods of 2009.: (a) 25 Oct-2 Dec; (b) 3 Dec-10 Dec; (c) 11 Dec-18 Dec; (d) 19 Dec-26 Dec (http://ladsweb.nascom.nasa.gov/ browse_images/13_browser.html)

into the water column in the Basin, which has a significantly smaller fractionation effect of $0-5 \%$ due to control of overall $\mathrm{NO}_{3}^{-}$removal rate by transport through the sediments (Brandes and Devol, 2002, Lehmann et al., 2007).

\subsubsection{Dust deposition signal in the surface waters south of Cape Verde}

In marked contrast to the Pacific study region, most $\delta^{15} \mathrm{~N}$ $\mathrm{NO}_{3}^{-}$values from the Atlantic (Fig. 8b) stay close to the ocean average value of $5.2 \%$ (Supplementary material, Table 1 (Sigman et al., 2009)). In part this can be explained by the absence of significant fixed-N removal in this region (N'values remain positive, data not shown (Gruber and Sarmiento, 1997)). Notable also was the complete absence of any trend towards higher values associated with partial nitrate utilization in fully-oxygenated, near-surface waters on the M80 samples (stations south to Cape Verde). Significant increases of $\delta^{15} \mathrm{~N}$ (up to $12 \%$ ) in surface waters were only observed at shallow stations very close to the African coast (data from L'Atalante cruise in 2008, not shown) that are likely associated with partial phytoplankton uptake of upwelled $\mathrm{NO}_{3}^{-}$(Altabet, 2001; Altabet and Francois, 1994).

Decreasing values of $\delta^{15} \mathrm{~N}$ of DIN towards the surface have been reported previously for Monterey Bay (Wankel et al., 2007), and for near-surface samples collected close to the Azores Front $\left(30-35^{\circ} \mathrm{N}\right.$ ) (Bourbonnais et al., 2009) and at Bermuda (Knapp et al., 2010). The lowest values published from this general region (Bourbonnais et al., 2009) were $\sim 3.5 \%$ at a depth of $100 \mathrm{~m}$. Our data indicate very similar values at this depth. The relatively low values of $3.5 \%$ were attributed by Bourbonnais et al. (2009) to the effects of nitrogen fixation, which can result in remineralised DIN with typical values of $-1 \%$ o $(-2 \%$ o to $+2 \%$ ) (Carpenter et al., 1997; Montoya et al., 2002). The strongly negative $\delta^{15} \mathrm{~N}$ values measured in surface waters south of Cape Verde (e.g. down to $-5.5 \%$ o, Fig. 5) have not been observed before in oceanic surface waters and cannot be explained by ammonification and nitrification of organic nitrogen produced by nitrogen fixers. On the other hand, very low values of $\delta^{15} \mathrm{~N}(\sim-7 \%$ o of aerosol nitrate have been measured in samples of atmospheric dust from this region (Baker et al., 2007; Morin et al., 2009). Similarly low, negative values have been measured in samples of atmospheric dust originating in the Sahara that were collected from the eastern Mediterranean (Wankel et al., 2010). Recent work (Knapp et al., 2010) shows that the wet deposition flux of fixed-N at Bermuda can be comparable to estimates of biological $\mathrm{N}_{2}$ fixation rates in surface waters. The $\delta^{15} \mathrm{~N}^{-\mathrm{NO}_{3}^{-}}$in wet deposition at Bermuda was significantly lower $(-4.5 \%)$ then $\delta^{15} \mathrm{~N}$ added by oceanic $\mathrm{N}_{2}$ fixation $(-2$ to $0 \%$ ) (Hastings et al., 2003; Knapp et al., 2010). For our study region, dry deposition of dust from the Sahara is likely to dominate the $\mathrm{N}$-flux (Duarte et al., 2006).

The N-flux due to diapycnal mixing of $\mathrm{NO}_{3}^{-}$from below in the eastern Atlantic $\left(28^{\circ} 30^{\prime} \mathrm{N}, 23^{\circ} \mathrm{W}\right)$ has been estimated to be $140 \mu \mathrm{mol} / \mathrm{m}^{2} /$ day and was statistically indistinguishable from the integrated rate of nitrate assimilation (Lewis et al., 1986). Later studies in the oligotrophic north Atlantic and at Cape Verde region come to values of about $7 \mathrm{mg} \mathrm{N} \mathrm{m}^{-2} \mathrm{~d}^{-1}$ (or $\sim 500 \mu \mathrm{mol} / \mathrm{m}^{2} /$ day) (Klein and Siedler, 1995) and at region close to Mauretania to almost double value of about $1037 \mu \mathrm{mol} / \mathrm{m}^{2} /$ day, calculated from the cruises data during high upwelling season (Schafstall et al., 2010). According to Baker et al. (2007) the dry deposition $\mathrm{N}$ flux of soluble aerosol at $20^{\circ} \mathrm{W}$ in the Atlantic ocean is $80-120 \mu \mathrm{mol} / \mathrm{m}^{2} /$ day, while wet deposition is 50 $70 \mu \mathrm{mol} / \mathrm{m}^{2} /$ day. Duarte (2006), for example, estimated a dry deposition $\mathrm{N}$ flux of $280 \pm 70 \mu \mathrm{mol} / \mathrm{m}^{2} /$ day in tropical Atlantic region, which is significant in comparison to the diapycnal flux. This deposition flux is sufficient to supply the observed DIN inventory of the top $20 \mathrm{~m}\left(0.2 \mu \mathrm{moll}^{-1}\right)$ within two weeks.

The most negative $\delta^{15} \mathrm{~N}$ values in surface water were observed at stations south of the Cape Verde Islands, which 
is also the region with the highest Saharan dust deposition (Schepanski et al., 2009; Tanaka and Chiba, 2006). A few days before our samples were collected on M80, an intensive dust event took place, and this may have influenced the $\delta^{15} \mathrm{~N}$ values observed. Satellite imagery from November and December 2009 are shown in Fig. 10 and indicate a significant dust event in the region over the period immediately prior to our samples being collected (between 26 November and 12 December 2009).

Under these conditions, the nitrogen loading to the surface layer cannot be considered to be in a steady state. We therefore examined extreme scenarios with dry deposition $\mathrm{N}$ flux dominating and for balance with diapycnal mixing and assimilation (Table 1). Total $\mathrm{N}$ flux $\left(\mathrm{F}_{\text {total }}\right)$ is the sum of two sources from atmospheric deposition $\left(\mathrm{F}_{\text {dust }}\right.$, initial value of $\delta^{15} \mathrm{~N}$-dust $\left.=-7 \% \circ\right)$ and diapycnal mixing $\left(\mathrm{F}_{\text {mix }}\right.$, initial value of $\delta^{15} \mathrm{~N}$-mixing $=5 \%$ o and one nitrogen sink from assimilation $\left(\mathrm{F}_{\text {assimilation }}\right)$. The fractionation factor for assimilation can vary with environmental conditions and dominant phytoplankton species. In oligotrophic waters, however, observed isotope fractionation will be close to zero due to complete $\mathrm{NO}_{3}^{-}$utilization. Assuming that utilized $\mathrm{NO}_{3}^{-}$has an oceanaverage value of $\delta^{15} \mathrm{~N}=5 \%$ and fractionation factor close to zero, the assimilation will decrease nitrate concentration but increase $\delta^{15} \mathrm{~N}$ of it in ambient waters by $5 \%$, thus $\delta^{15} \mathrm{~N}$ assimilation $=-5 \%$.

In the first scenario, $90 \%$ of total nitrogen derives from dust deposition and only $10 \%$ is from diapycnal mixing. This scenario results in a $\delta^{15} \mathrm{~N}$ value of $-5.8 \%$, very close to observations. The second scenario assumes equal contribution from those two nitrogen sources resulting in a $\delta^{15} \mathrm{~N}$ of $-1 \%$, while the third includes assimilation as a nitrogen sink and result in $\delta^{15} \mathrm{~N}$ of $+1 \%$ (Table 1 ).

These scenarios do not take into consideration an isotopic signal from $\mathrm{N}_{2}$ fixation. They do show, however, that under non-steady state conditions, such as shortly after dust deposition events, the $\delta^{15} \mathrm{~N}$ for $\mathrm{NO}_{3}^{-}$in surface waters can decrease to $-5.8 \%$. Thus, atmospheric dust $\mathrm{N}$ deposition should be taken into account, together with the oceanic $\mathrm{N}_{2}$ fixation, in explaining the low $\delta^{15} \mathrm{~N} \mathrm{NO}_{3}^{-}$pool observed in subtropical thermoclines (Brandes et al., 1998; Karl et al., 2002; Knapp et al., 2005; Wannicke et al., 2010).

\section{Summary and conclusions}

In this paper we have presented an extensive amount of new data for nitrogen isotope and key nitrogen species, such as $\mathrm{N}_{2} \mathrm{O}$, collected from OMZ regions in the eastern tropical North Atlantic and eastern tropical South Pacific. These regions have strongly contrasting $\mathrm{O}_{2}$ concentrations and $\mathrm{N}$ cycling processes. Measurements with near identical techniques in both oceans, reveal that whereas deep waters $(>2000 \mathrm{~m})$ share near-identical values of $\delta^{15} \mathrm{~N}$ DIN $(5.3 \pm 0.4 \%$ ) , there are significant to major differences between the two OMZs in both surface and intermediate waters. The same AAIW water mass, for instance, has in the Pacific $\delta^{15} \mathrm{~N}$-DIN average value of $6.7 \pm 0.8 \%$ and in the Atlantic of $5.5 \pm 0.6 \%$ (Supplementary material, Table 1). According to a Student t-test, the difference is highly significant $(p<0.01)$. This difference can be due to N-loss in the Pacific, increasing $\delta^{15} \mathrm{~N}$ signal of the water mass, and/or nitrogen fixation in the Atlantic, driving $\delta^{15} \mathrm{~N}$ signal in the opposite direction. Strongest differences in $\delta^{15} \mathrm{~N}-\mathrm{DIN}$ in the two study regions are located in depth $100-500 \mathrm{~m}$ in the OMZs. In the Pacific $\delta^{15} \mathrm{~N}$ values tend towards strongly positive values as a result of $\mathrm{N}$-loss processes within the $\mathrm{OMZ}$ and partial $\mathrm{NO}_{3}^{-}$utilization in surface waters, while in the Atlantic the values stay close to $\sim 5.4 \%$ on average.

Co-located measurements of $\mathrm{N}_{2} \mathrm{O}$ and stable $\mathrm{N}$-isotopes in waters with $\left[\mathrm{O}_{2}\right]<\sim 5 \mu \mathrm{moll} \mathrm{l}^{-1}$ reveal a clear signal of canonical denitrification, although its quantitative significance for overall $\mathrm{N}$-loss, relative to anammox, cannot be assessed. The correlations of $\mathrm{N}_{2} \mathrm{O}$ with $\delta^{15} \mathrm{~N}^{-\mathrm{NO}_{3}^{-}}$and $\mathrm{AOU}$ for waters with $\left[\mathrm{O}_{2}\right]>50 \mu \mathrm{mol}^{-1}$ are similar in both OMZs, reflecting similar $\mathrm{N}_{2} \mathrm{O}$ yields during nitrification. However, waters with $5<\left[\mathrm{O}_{2}\right]<50 \mu \mathrm{mol}^{-1}$ in the Pacific exhibit correlations that are suggestive of a $300 \%$ higher relative $\mathrm{N}_{2} \mathrm{O}$ yield.

Whereas $\delta^{15} \mathrm{~N}-\mathrm{NO}_{3}^{-}$values in surface waters of the Pacific OMZ region are strongly positive, being controlled by partial nutrient utilization and a ${ }^{15} \mathrm{~N}$-enriched $\mathrm{NO}_{3}^{-}$supply affected by subsurface denitrification, the oligotrophic surface waters south of Cape Verde in the Atlantic exhibit negative values of $\delta^{15} \mathrm{~N}(-5$ to $+2 \%$ ). The negative values are too low to be explained by $\mathrm{N}$-fixation and we show that they are most likely the result of a transient input of $\mathrm{NO}_{3}^{-}$associated with atmospheric deposition of Saharan dust. This implies that atmospheric dust input as well as nitrogen fixation should be considered in budgets and explanations of upper ocean stable $\mathrm{N}$ isotope data, especially in the Atlantic region.

Within the Pacific OMZ, correlation of $\delta^{15} \mathrm{~N}$ with measures of $\mathrm{N}$-loss gives a calculated apparent fractionation factor for $\delta^{15} \mathrm{~N}_{-\mathrm{NO}_{3}^{-}}\left(\varepsilon_{\mathrm{r}}=11.4 \pm 0.3 \%\right.$ o $)$ which is low compared to canonical values, but close to a value estimated by the only prior study in this region (Liu, 1979). Sub-division of the data into shelf and offshore stations resulted in improved correlations and very different apparent fractionation factors for the two depth-regimes $\left(\varepsilon_{\mathrm{d} \text {-offshore }}=16 \pm 0.5 \% ; \varepsilon_{\mathrm{d} \text {-shelf }}\right.$ $=7.6 \pm 0.6 \%$ o). Whereas the offshore value lies close to the $\sim 20 \%$ fractionation factor of denitrification (Brandes et al., 1998; Granger et al., 2008), the much lower apparent fractionation factor for shelf waters likely reflects a larger contribution from sedimentary denitrification (fractionation factor of 1.5\%o; (Brandes and Devol, 2002). We note that the fractionation effect from the complete set of stations $\left(\varepsilon^{*}=\right.$ $11.4 \pm 0.3 \%$ ) lies reasonably close to an apparent global fractionation factor for OMZ denitrification of $12 \%$ which was calculated for a steady state 50:50 balance between water column and sedimentary denitrification (Altabet, 2007). 
Supplementary material related to this article is available online at: http://www.biogeosciences.net/9/203/2012/ bg-9-203-2012-supplement.pdf.

Acknowledgements. The authors thank Frank Malien, Gert Petrick and Karen Stange for technical assistance and Andreas Oschlies helpful discussion. The work was supported by the DFG-funded Sonderforschungsbereich 754 "Climate-Biogeochemistry Interactions in the Tropical Ocean" and SOPRAN (Surface Ocean Processes in the Anthropocene: www.sopran.pangaea.de; FKZ 03F0462A).

Edited by: M. Voss

\section{References}

Altabet, M. A.: Nitrogen isotopic evidence for micronutrient control of fractional $\mathrm{NO}_{3}^{-}$utilization in the equatorial Pacific, Limnol. Oceanogr., 46, 368-380, 2001.

Altabet, M. A.: Constraints on oceanic $\mathrm{N}$ balance/imbalance from sedimentary $15 \mathrm{~N}$ records, Biogeosciences, 4, 75-86, doi:10.5194/bg-4-75-2007, 2007.

Altabet, M. A. and Francois, R.: Sedimentary Nitrogen Isotopic Ratio as a Recorder for Surface Ocean Nitrate Utilization, Glob. Biogeochem. Cy., 8, 103-116, 1994.

Baker, A. R., Weston, K., Kelly, S. D., Voss, M., Streu, P., and Cape, J. N.: Dry and wet deposition of nutrients from the tropical Atlantic atmosphere: Links to primary productivity and nitrogen fixation, Deep-Sea Res. Pt. I, 54, 1704-1720, doi:10.1016/j.dsr.2007.07.001, 2007.

Bange, H. W.: Gaseous nitrogen compounds (NO, $\mathrm{N}_{2} \mathrm{O}, \mathrm{N}_{2}, \mathrm{NH}_{3}$ ) in the ocean, in: Nitrogen in Marine Environment, 2nd Edn., edited by: Capone, D. G., Bronk, D. A., Mulholland, M. R., and Carpenter, E. J., Amsterdam, 2008.

Bange, H. W., Naqvi, S. W. A., and Codispoti, L. A.: The nitrogen cycle in the Arabian Sea, Prog. Oceanogr., 65, 145-158, doi:10.1016/j.pocean.2005.03.002, 2005.

Barford, C. C., Montoya, J. P., Altabet, M. A., and Mitchell, R.: Steady-state nitrogen isotope effects of $\mathrm{N}_{2}$ and $\mathrm{N}_{2} \mathrm{O}$ production in Paracoccus denitrificans, Appl. Environ. Microb., 65, 989994, 1999.

Bourbonnais, A., Lehmann, M. F., Waniek, J. J., and SchulzBull, D. E.: Nitrate isotope anomalies reflect $\mathrm{N}_{2}$ fixation in the Azores Front region (subtropical NE Atlantic), J. Geophys. Res.Oceans, 114, C03003, doi:10.1029/2007JC004617, 2009.

Brandes, J. A. and Devol, A. H.: A global marine-fixed nitrogen isotopic budget: Implications for Holocene nitrogen cycling, Global Biogeochem. Cy., 16, 1120-1134, doi:10.1029/2001GB001856, 2002.
Brandes, J. A., Devol, A. H., Yoshinari, T., Jayakumar, D. A., and Naqvi, S. W. A.: Isotopic composition of nitrate in the central Arabian Sea and eastern tropical North Pacific: A tracer for mixing and nitrogen cycles, Limnol. Oceanogr., 43, 1680-1689, doi:10.4319/lo.1998.43.7.1680, 1998.

Carpenter, E. J., Harvey, H. R., Fry, B., and Capone, D. G.: Biogeochemical tracers of the marine cyanobacterium Trichodesmium, Deep-Sea Res. Pt. I, 44, 27-38, doi:10.1016/S0967-0637(96)00091-X, 1997.

Casciotti, K. L.: Inverse kinetic isotope fractionation during bacterial nitrite oxidation, Geochim. Cosmochim. Ac., 73, 20612076, doi:0.1016/j.gca.2008.12.022, 2009.

Casciotti, K. L. and McIlvin, M. R.: Isotopic analyses of nitrate and nitrite from reference mixtures and application to Eastern Tropical North Pacific waters, Mar. Chem., 107, 184-201, doi:10.1016/j.marchem.2007.06.021, 2007.

Chavez, F. P. and Messie, M.: A comparison of Eastern Boundary Upwelling Ecosystems, Prog. Oceanogr., 83, 80-96, doi:10.1016/j.pocean.2009.07.032, 2009.

Cline, J. D. and Richards, F. A.: Oxygen deficient conditions and nitrate reduction in Eastern Tropical North-Pacific Ocean, Limnol. Oceanogr., 17, 885-900, 1972.

Codispoti, L. A.: Interesting Times for Marine $\mathrm{N}_{2} \mathrm{O}$, Science, 327, 1339-1340, doi:10.1126/science.1184945, 2010.

Codispoti, L. A., Brandes, J. A., Christensen, J. P., Devol, A. H., Naqvi, S. W. A., Paerl, H. W., and Yoshinari, T.: The oceanic fixed nitrogen and nitrous oxide budgets: Moving targets as we enter the anthropocene?, Sci. Mar., 65, 85-105, doi:10.3989/scimar.2001.65s285, 2001.

Deutsch, C., Gruber, N., Key, R. M., Sarmiento, J. L., and Ganachaud, A.: Denitrification and $\mathrm{N}_{2}$ fixation in the Pacific Ocean, Global Biogeochem. Cy., 15, 483-506, doi:10.1029/2000GB001291, 2001.

Devol, A. H.: Denitrification including anammox, in: Nitrogen in the Marine Environment 2Edn., edited by: Capone, D. G., Bronk, D. A., Mulholland, M. R., and Carpenter, E. J., Elsevier Inc., Amsterdam, 263-302, 2008.

Duarte, C. M., Dachs, J., Llabres, M., Alonso-Laita, P., Gasol, J. M., Tovar-Sanchez, A., Sanudo-Wilhemy, S., and Agusti, S.: Aerosol inputs enhance new production in the subtropical northeast Atlantic, J. Geophys. Res.-Biogeo., 111, G04006, doi:10.1029/2005jg000140, 2006.

Duce, R. A., LaRoche, J., Altieri, K., Arrigo, K. R., Baker, A. R., Capone, D. G., Cornell, S., Dentener, F., Galloway, J., Ganeshram, R. S., Geider, R. J., Jickells, T., Kuypers, M. M., Langlois, R., Liss, P. S., Liu, S. M., Middelburg, J. J., Moore, C. M., Nickovic, S., Oschlies, A., Pedersen, T., Prospero, J., Schlitzer, R., Seitzinger, S., Sorensen, L. L., Uematsu, M., Ulloa, O., Voss, M., Ward, B., and Zamora, L.: Impacts of Atmospheric Anthropogenic Nitrogen on the Open Ocean, Science, 320, 893 897, doi:10.1126/science.1150369, 2008.

Elkins, J. W., Wofsy, S. C., McElroy, M. B., Kolb, C. E., and Kaplan, W. A.: Aquatic sources and sinks for nitrous oxide, Nature, 275, 602-606, doi:10.1038/275602a0, 1978.

Fiedler, P. C. and Talley, L. D.: Hydrography of the eastern tropical Pacific: A review, Prog. Oceanogr., 69, 143-180, doi:10.1016/j.pocean.2006.03.008, 2006. 
Frame, C. H. and Casciotti, K. L.: Biogeochemical controls and isotopic signatures of nitrous oxide production by a marine ammonia-oxidizing bacterium, Biogeosciences, 7, 2695-2709, doi:10.5194/bg-7-2695-2010, 2010.

Freing, A., Wallace, D. W. R., Tanhua, T., Walter, S., and Bange, H. W.: North Atlantic production of nitrous oxide in the context of changing atmospheric levels, Global Biogeochem. Cy., 23, GB4015, doi:10.1029/2009gb003472, 2009.

Galan, A., Molina, V., Thamdrup, B., Woebken, D., Lavik, G., Kuypers, M. M. M., and Ulloa, O.: Anammox bacteria and the anaerobic oxidation of ammonium in the oxygen minimum zone off northern Chile, Deep-Sea Res. Pt. II, 56, 1125-1135, doi:10.1016/j.dsr2.2008.09.016, 2009.

Glessmer, M. S., Eden, C., and Oschlies, A.: Contribution of oxygen minimum zone waters to the coastal upwelling off Mauritania, Prog. Oceanogr., 83, 143-150, doi:10.1016/j.pocean.2009.07.015, 2009.

Goreau, T. J., Kaplan, W. A., Wofsy, S. C., McElroy, M. B., Valois, F. W., and Watson, S. W.: Production of $\mathrm{NO}_{2}^{-}$and $\mathrm{N}_{2} \mathrm{O}$ by Nitrifying Bacteria at Reduced Concentrations of Oxygen, Appl. Environ. Microb., 40, 526-532, 1980.

Granger, J., Sigman, D. M., Needoba, J. A., and Harrison, P. J.: Coupled nitrogen and oxygen isotope fractionation of nitrate during assimilation by cultures of marine phytoplankton, Limnol. Oceanogr., 49, 1763-1773, doi:10.4319/lo.2004.49.5.1763, 2004.

Granger, J., Sigman, D. M., Lehmann, M. F., and Tortell, P. D.: Nitrogen and oxygen isotope fractionation during dissimilatory nitrate reduction by denitrifying bacteria, Limnol. Oceanogr., 53, 2533-2545, doi:10.4319/lo.2008.53.6.2533, 2008.

Grasshoff, K., Kremling, K., and Ehrhardt, M.: Methods of seawater analysis - third, completely revised and extended version, Seawater Analysis Wiley-VCH, 1999.

Gruber, N.: The Marine Nitrogen Cycle: Overview and Challanges, in: Nitrogen in Marine Environment, edited by: Capone, D. G., Bronk, D. A., Mulholland, M. R., and Carpenter, E. J., Elsevier Inc., 1-51, 2008.

Gruber, N. and Sarmiento, J. L.: Global patterns of marine nitrogen fixation and denitrification, Global Biogeochem. Cy., 11, 235266, doi:10.1029/97GB00077, 1997.

Hamersley, M. R., Lavik, G., Woebken, D., Rattray, J. E., Lam, P., Hopmans, E. C., Damste, J. S. S., Kruger, S., Graco, M., Gutierrez, D., and Kuypers, M. M. M.: Anaerobic ammonium oxidation in the Peruvian oxygen minimum zone, Limnol. Oceanogr., 52, 923-933, doi:10.4319/lo.2007.52.3.0923, 2007.

Hansell, D. A., Bates, N. R., and Olson, D. B.: Excess nitrate and nitrogen fixation in the North Atlantic Ocean, Mar. Chem., 84, 243-265, doi:10.1016/j.marchem.2003.08.004, 2004.

Hastings, M. G., Sigman, D. M., and Lipschultz, F.: Isotopic evidence for source changes of nitrate in rain at Bermuda, J. Geophys. Res.-Atmos., 108, 4790, doi:10.1029/2003jd003789, 2003.

Helly, J. J. and Levin, L. A.: Global distribution of naturally occurring marine hypoxia on continental margins, Deep-Sea Res. Pt. I, 51, 1159-1168, doi:10.1016/j.dsr.2004.03.009, 2004.

Karl, D., Michaels, A., Bergman, B., Capone, D., Carpenter, E., Letelier, R., Lipschultz, F., Paerl, H., Sigman, D., and Stal, L.: Dinitrogen fixation in the world's oceans, Biogeochemistry, 57, 47-98, doi:10.1023/A:1015798105851, 2002.
Karstensen, J., Stramma, L., and Visbeck, M.: Oxygen minimum zones in the eastern tropical Atlantic and Pacific oceans, Prog. Oceanogr., 77, 331-350, doi:10.1016/j.pocean.2007.05.009, 2008.

Klein, B. and Siedler, G.: Isopycnal and Diapycnal Mixing at the Cape-Verde Frontal Zone, J. Phys. Oceanogr., 25, 1771-1787, 1995.

Knapp, A. N., Sigman, D. M., and Lipschultz, F.: N isotopic composition of dissolved organic nitrogen and nitrate at the Bermuda Atlantic time-series study site, Global Biogeochem. Cy., 19, GB1018, doi:10.1029/2004GB002320, 2005.

Knapp, A. N., Hastings, M. G., Sigman, D. M., Lipschultz, F., and Galloway, J. N.: The flux and isotopic composition of reduced and total nitrogen in Bermuda rain, Mar. Chem., 120, 83-89, doi:10.1016/j.marchem.2008.08.007, 2010.

Koeve, W. and Kähler, P.: Heterotrophic denitrification vs. autotrophic anammox quantifying collateral effects on the oceanic carbon cycle, Biogeosciences, 7, 2327-2337, doi:10.5194/bg-72327-2010, 2010.

Lam, P., Lavik, G., Jensen, M. M., van de Vossenberg, J., Schmid, M., Woebken, D., Dimitri, G., Amann, R., Jetten, M. S. M., and Kuypers, M. M. M.: Revising the nitrogen cycle in the Peruvian oxygen minimum zone, Proceedings of the National Academy of Sciences of the United States of America, 106, 4752-4757, doi:10.1073/pnas.0812444106, 2009.

Lehmann, M. F., Sigman, D. M., McCorkle, D. C., Granger, J., Hoffmann, S., Cane, G., and Brunelle, B. G.: The distribution of nitrate ${ }^{15} \mathrm{~N} /{ }^{14} \mathrm{~N}$ in marine sediments and the impact of benthic nitrogen loss on the isotopic composition of oceanic nitrate, Geochim. Cosmochim. Ac., 71, 5384-5404, doi:10.1016/j.gca.2007.07.025, 2007.

Lewis, M. R., Hebert, D., Harrison, W. G., Platt, T., and Oakey, N. S.: Vertical Nitrate Fluxes in the Oligotrophic Ocean, Science, 234, 870-873, doi:10.1126/science.234.4778.870, 1986.

Liu, K.-K.: Geochemistry of Inorganic Nitrogen Compounds in Two Marine Environments: The Santa Barbara Basin and the Ocean off Peru, PhD in Geochemistry, University of California, Los Angeles, 1979.

Lomas, M. W. and Lipschultz, F.: Forming the primary nitrite maximum: Nitrifiers or phytoplankton?, Limnology and Oceanography, 51, 2453-2467, doi:10.4319/lo.2006.51.5.2453, 2006.

Löscher, C. R., Kock, A., Könneke, M., LaRoche, J., Bange, H. W., and Schmitz, R. A.: Production of oceanic nitrous oxide by ammonia-oxidizing archaea, Biogeosciences, in preparation, 2011.

McIlvin, M. R. and Altabet, M. A.: Chemical Conversion of Nitrate and Nitrite to Nitrous Oxide for Nitrogen and Oxygen Isotopic Analysis in Freshwater and Seawater, Anal. Chem., 77, 55895595, doi:10.1021/ac050528s, 2005.

Michaels, A. F., Olson, D., Sarmiento, J. L., Ammerman, J. W., Fanning, K., Jahnke, R., Knap, A. H., Lipschultz, F., and Prospero, J. M.: Inputs, losses and transformations of nitrogen and phosphorus in the pelagic North Atlantic Ocean, Biogeochemistry, 35, 181-226, doi:10.1007/BF02179827, 1996.

Monteiro, F. M. and Follows, M.: Nitrogen fixation and preferential remineralization of phosphorus in the North Atlantic: Model insights, Eos Trans., AGU, 87(36), Ocean Science Meeting OS35A-06, 2006. 
Montoya, J. P., Carpenter, E. J., and Capone, D. G.: Nitrogen fixation and nitrogen isotope abundances in zooplankton of the oligotrophic North Atlantic, Limnol. Oceanogr., 47, 1617-1628, 2002.

Morin, S., Savarino, J., Frey, M. M., Domine, F., Jacobi, H. W., Kaleschke, L., and Martins, J. M. F.: Comprehensive isotopic composition of atmospheric nitrate in the Atlantic Ocean boundary layer from 65 degrees S to 79 degrees N, J. Geophys. Res.Atmos., 114, D05303, doi:10.1029/2008JD010696, 2009.

Naqvi, S. W. A., Bange, H. W., Farías, L., Monteiro, P. M. S., Scranton, M. I., and Zhang, J.: Marine hypoxia/anoxia as a source of $\mathrm{CH}_{4}$ and $\mathrm{N}_{2} \mathrm{O}$, Biogeosciences, 7, 2159-2190, doi:10.5194/bg7-2159-2010, 2010.

Nevison, C., Butler, J. H., and Elkins, J. W.: Global distribution of $\mathrm{N}_{2} \mathrm{O}$ and the Delta $\mathrm{N}_{2} \mathrm{O}-\mathrm{AOU}$ yield in the subsurface ocean, Global Biogeochem. Cy., 17, 1119, doi:10.1029/2003gb002068, 2003.

O'Connor, B. M., Fine, R. A., Maillet, K. A., and Olson, D. B.: Formation rates of subtropical underwater in the Pacific Ocean, Deep-Sea Res. Pt. I, 49, 1571-1590, doi:10.1016/S09670637(02)00087-0, 2002.

Oudot, C., Andrie, C., and Montel, Y.: Nitrous oxide production in the tropical Atlantic Ocean, Deep-Sea Res. Pt. I., 37, 183-202, doi:10.1016/0198-0149(90)90123-D, 1990.

Oudot, C., Jean-Baptiste, P., Fourre, E., Mormiche, C., Guevel, M., Ternon, J. F., and Le Corre, P.: Transatlantic equatorial distribution of nitrous oxide and methane, Deep-Sea Res. Pt. I, 49, 1175-1193, 2002.

Qu, T., Gao, S., Fukumori, I., Fine, R. A., and Lindstrom, E. J.: Origin and Pathway of Equatorial $13{ }^{\circ} \mathrm{C}$ Water in the Pacific Identified by a Simulated Passive Tracer and Its Adjoint, J. Phys. Oceanogr., 39, 1836-1853, doi:10.1175/2009JPO4045.1, 2009.

Ryabenko, E., Altabet, M. A., and Wallace, D. W. R.: Effect of chloride on the chemical conversion of nitrate to nitrous oxide for $\delta^{15} \mathrm{~N}$ analysis, Limnol. Oceanogr. Methods, 7, 545-552, 2009.

Schafstall, J., Dengler, M., Brandt, P., and Bange, H.: Tidalinduced mixing and diapycnal nutrient fluxes in the Mauritanian upwelling region, J. Geophys. Res.-Oceans, 115, 19, doi:10.1029/2009jc005940, 2010.

Schepanski, K., Tegen, I., and Macke, A.: Saharan dust transport and deposition towards the tropical northern Atlantic, Atmos. Chem. Phys., 9, 1173-1189, doi:10.5194/acp-9-1173-2009, 2009.

Schott, F. A., McCreary, J. P., and Johnson, G. C.: Shallow overturning circulations of the tropical-subtropical oceans, in: Earth Climate: The Ocean-Atmosphere Interaction, edited by: Wang, C., Xie, S. P., and Carton, J. A., American Geophysical Union, Washington D.C. , 261-304, 2004.

Sigman, D. M., Altabet, M. A., Michener, R., McCorkle, D. C., Fry, B., and Holmes, R. M.: Natural abundance-level measurement of the nitrogen isotopic composition of oceanic nitrate: an adaptation of the ammonia diffusion method, Mar. Chem., 57, 227-242, doi:10.1016/S0304-4203(97)00009-1, 1997.

Sigman, D. M., Robinson, R., Knapp, A. N., van Geen, A., McCorkle, D. C., Brandes, J. A., and Thunell, R. C.: Distinguishing between water column and sedimentary denitrification in the Santa Barbara Basin using the stable isotopes of nitrate, Geochem. Geophys. Geosyst., 4(5), 1040, doi:10.1029/2002gc000384, 2003.
Sigman, D. M., DiFiore, P. J., Hain, M. P., Deutsch, C., Wang, Y., Karl, D. M., Knapp, A. N., Lehmann, M. F., and Pantoja, S.: The dual isotopes of deep nitrate as a constraint on the cycle and budget of oceanic fixed nitrogen, Deep-Sea Res. Pt. I, 56, 14191439, doi:10.1016/j.dsr.2009.04.007, 2009.

Stein, L. Y. and Yung, Y. L.: Production, isotopic composition, and atmospheric fate of biologically produced nitrous oxide, Annu. Rev. Earth Pl. Sc., 31, 329-356, doi:10.1146/annurev.earth.31.110502.080901, 2003.

Stramma, L., Hüttl, S., and Schafstall, J.: Water masses and currents in the upper tropical northeast Atlantic off northwest Africa, J. Geophys. Res., 110, C12006, doi:10.1029/2005jc002939, 2005.

Stramma, L., Johnson, G. C., Firing, E., and Schmidtko, S.: Eastern Pacific oxygen minimum zones: Supply paths and multidecadal changes, J. Geophys. Res.-Oceans, 115, C09011, doi:10.1029/2009jc005976, 2010.

Strous, M., Heijnen, J. J., Kuenen, J. G., and Jetten, M. S. M.: The sequencing batch reactor as a powerful tool for the study of slowly growing anaerobic ammonium-oxidizing microorganisms, Appl. Microbiol. Biotechnol., 50, 589-596, doi:10.1007/s002530051340, 1998.

Tanaka, T. Y. and Chiba, M.: A numerical study of the contributions of dust source regions to the global dust budget, Global Planet. Change, 52, 88-104, doi:10.1016/j.gloplacha.2006.02.002, 2006.

Thamdrup, B., Dalsgaard, T., Jensen, M. M., Ulloa, O., Farias, L., and Escribano, R.: Anaerobic ammonium oxidation in the oxygen-deficient waters off northern Chile, Limnol. Oceanogr., 51, 2145-2156, doi:10.4319/lo.2006.51.5.2145, 2006.

Toggweiler, J. R., Dixon, K., and Broecker, W. S.: The Peru Upwelling and the Ventilation of the South Pacific Thermocline, J. Geophys. Res., 96, 20467-20497, doi:10.1029/91jc02063, 1991.

van de Graaf, A. A., de Bruijn, P., Robertson, L. A., Jetten, M. S. M., and Kuenen, J. G.: Autotrophic growth of anaerobic ammonium-oxidizing micro-organisms in a fluidized bed reactor, Microbiology, 142, 2187-2196, doi:10.1099/13500872-1428-2187, 1996.

Voss, M. and Montoya, J. P.: Nitrogen Cycle, Oceans apart, Nature, 461, 49-50, doi:10.1038/461049a, 2009.

Voss, M., Dippner, J. W., and Montoya, J. P.: Nitrogen isotope patterns in the oxygen-deficient waters of the Eastern Tropical North Pacific Ocean, Deep-Sea Res. Pt. I, 48, 1905-1921, doi:10.1016/S0967-0637(00)00110-2, 2001.

Walter, S., Bange, H. W., and Wallace, D. W. R.: Nitrous oxide in the surface layer of the tropical North Atlantic Ocean along a west to east transect, Geophys. Res. Lett., 31, L23S07, doi:10.1029/2004g1019937, 2004.

Walter, S., Bange, H. W., Breitenbach, U., and Wallace, D. W. R.: Nitrous oxide in the North Atlantic Ocean, Biogeosciences, 3, 607-619, doi:10.5194/bg-3-607-2006, 2006.

Wankel, S. D., Kendall, C., Pennington, J. T., Chavez, F. P., and Paytan, A.: Nitrification in the euphotic zone as evidenced by nitrate dual isotopic composition: Observations from Monterey Bay, California, Global Biogeochem. Cy., 21, GB2009, doi:10.1029/2006gb002723, 2007.

Wankel, S. D., Chen, Y., Kendall, C., Post, A. F., and Paytan, A.: Sources of aerosol nitrate to the Gulf of Aqaba: Evidence from delta $\mathrm{N}-15$ and delta O-18 of nitrate and trace metal chemistry, Mar. Chem., 120, 90-99, doi:10.1016/j.marchem.2009.01.013, 
2010.

Wannicke, N., Liskow, I., and Voss, M.: Impact of diazotrophy on $\mathrm{N}$ stable isotope signatures of nitrate and particulate organic nitrogen: case studies in the north-eastern tropical Atlantic Ocean, Isot. Environ. Health Stud., 46, 337-354, doi:10.1080/10256016.2010.505687, 2010.
Ward, B. B., Devol, A. H., Rich, J. J., Chang, B. X., Bulow, S. E., Naik, H., Pratihary, A., and Jayakumar, A.: Denitrification as the dominant nitrogen loss process in the Arabian Sea, Nature, 461, 78-81, doi:10.1038/nature08276, 2009.

Yoshinari, T.: Nitrous oxide in the sea, Mar. Chem., 4, 189-202, 1976. 